\title{
A Study on the Acceptance of Mobile Phones for Teaching and Learning with a Group of Pre-service Teachers in Hong Kong
}

\author{
Simon So \\ Hong Kong Institute of Education
}

\begin{abstract}
Ubiquitous devices offer new teaching and learning opportunities from K-12 to higher education settings. The integration of mobile facilities and Web technologies allows researchers and educators to explore different possibilities in m-Learning. In this study, a group of pre-service IT teachers in Hong Kong were introduced to the field of m-Learning by participating in a series of m-Learning activities. Three applications were designed and programmed with XTHML-MP/ WAP 2.0 technologies and supported by server-side Web technologies of PHP and MySQL. The research aimed at providing the opportunities for the teachers to explore this new trend in teaching and learning and to find out their acceptance of this approach.
\end{abstract}

Keywords: M-Learning, XTHML-MP, WAP 2.0

\section{Introduction}

The emergence of mobile and wireless technologies is already impacting education. New Internet technologies are being used to support mobile and wireless devices. In a field marked by such a rapid evolution, we cannot assume that the Web is the sole medium for computer-based learning. The combination of mobile and Web-based technologies opens a new horizon for educators. The use of ubiquitous devices for teaching and learning is increasingly popular in education.

In this research, a study of mobile learning was conducted with a group of pre-service teachers in Hong Kong. To investigate the innovative practice and the acceptance of mobile phones in teaching and learning, a set of m-Learning activities were developed by the author. Three activities were being carried out. A questionnaire was used to collect the data at the end of the activities. Data are analyzed and findings are then reported in this paper.

\section{Literature Review}

Over the period of the past ten years for the notion of m-Learning taking shape, the small and big projects around the world come and go. It is, however, difficult to comprehensively survey major m-Learning projects worldwide. Nevertheless, a number of past and current projects are highlighted in this paper. Interested readers could consult the various Websites and introductory articles listed in the reference section (BECTA, 2003 \& 2007; EDUCAUSE, n.d.; Futurelab, 2004 \& 2006; JISC, 2005; Sharples, 2007). 


\subsection{UK Projects}

Under the leadership of Professor Stephen Heppell, Ultralab has developed a reputation for innovation in learning technology with a number of projects in the area of mobile learning. The description of its numerous projects can be found in National Archive of Educational Computing, UK (NAEC, 2006). In particular, with the eVIVA project funded by the UK Qualifications and Curriculum Authority, a student can respond to questions about the ICT skills they have acquired over the phone. eVIVA enables students to compile online portfolios similar to the IT Competency checklist via SMS or voice messages and the Website. Students can also be assessed by taking exams via mobile phones. With the m-Learning project headed by Alice Mitchell and funded by the European Commission, young adults who are unemployed, under-employed and/or homeless take part in using specially designed $\mathrm{m}$-Learning materials on a mobile phone or a hand-held computer.

Recently, the Learning2Go project coordinated by the City of Wolverhampton takes the spotlight of mobile learning in UK (Learning2Go, 2008). Learning2Go uses mobile handheld devices to deliver multimedia content to students' classrooms and homes. The project is one of the largest involving handheld devices in the United Kingdom.

\subsection{European Projects}

MOBIlearn was a European-led research and development project involving 24 partners worldwide (MOBIlearn, 2006). The project aimed to explore mobile environments in education and training. It allowed the free circulation of knowledge and given its users to ubiquitous access to appropriate learning objects and contents.
The famous m-Learning project is a threeyear pan-European collaborative research and development initiative supported by the European Union. Some interesting tools and products can be found in the Website of m-Learning (n.d.). A number of reports by Jill Attewell, Carol Savill-Smith and others together with links to various documents including the series of MLEARN conferences can also be found in the Website.

A Swedish project, Mobile Learning, supported by the Leonardo Da Vinci programme of the European Commission has been formed to harness current and new technologies to provide new methods of learning and training (Mobile Learning, 2006). The project aims at developing courseware as part of a fully-functional mobile Learning Management System (mLMS). Ericsson is the major partner to this project and other partners are from Norway, Germany, Ireland and Hungary.

UniWap (Consortium, 2002; Alamäki \& Seppälä, 2002), a Finland project from the University of Helsinki, and KNOWMOBILE (Smørdal \& Gregory, 2005), a Norway project for medical students from the University of Oslo in 2000 to 2002, were some of the older but interesting m-Learning projects in Europe.

\subsection{United States Projects}

Project Numina, researchers at the University of North Carolina Wilmington, developed a mobile learning environment that fosters collaboration among students and between students and instructors (Heath et. al., 2005). Handheld applications including Student Response Systems (SRS) together with Mathematical and Scientific Applications are demonstrated in the mobile learning environment to support a 24/7 virtual learning community. 
The Harvard University's Handheld Devices for Ubiquitous Learning (HDUL) project sought to find out how ubiquitous devices such as cellphones, PDAs, and mobile gaming devices can enhance teaching and learning in university settings (Harvard, 2007). Integration of wireless handheld devices into eight courses at Harvard was reported.

Duke University actively engages mobile devices in education (Duke, 2008). iPods, PRS (clicker) devices, tablet PCs, and various mobile devices are used as instructional devices to support teaching and learning. Classroom assessment and polling using PRS devices was demonstrated to be effective instructional strategies.

\subsection{Hong Kong Projects}

Despite the fact that Hong Kong has the highest penetration rates of mobile service subscribers in the world at around $152 \%$ as of December 2007 (OFTA, 2008), Hong Kong has been a little slow to embark on the mobile technology in teaching and learning. Although mobile phones as the instructional tools in Hong Kong are yet to be developed, projects in mobile learning are highlighted. With the e3Learning project (Csete, Wong and Vogel, 2004) involving Hong Kong Polytechnic University, City University of Hong Kong and Chinese University of Hong Kong funded by University Grant Committee, it aims (a) to enrich students' learning environment by using well-designed Internet resources; (b) to extend students' learning space into the use of mobile equipment; and (c) to evaluate the impact of all e3Learning activities (e3Learn 2006).

\subsection{Other Studies and Projects}

There are a number of research works in m-Learning elsewhere in the world. For examples, the educational potential and an effective pedagogical model for m-Learning were studied by McManus (2002). Investigating the use of mobile technologies to support the learning processes in a university environment from the perspectives of effective design models, evaluation of learning processes in mobile learning environments, technological aspects of mobile learning, and integration with e-Learning systems were reported by Andronico et al. (2004). Hayes, Joyce and Pathak (2004) focused on the application of mobile technologies in education by making content of an e-commerce book easy to read, interactive and graphically aesthetic on a $3 \mathrm{G}$ phone. Mobile devices in interactive lectures were also reported by Scheele (2004).

\section{Focus of the Study}

The focus of this study is to discover the acceptance of mobile phones for teaching and learning among my pre-service students. This may link heavily to their daily operational uses of mobile phones. In general, there are three dimensions that are critically affecting the success of m-Learning as illustrated in Figure 1. Mobile phones have greater advantages in term of "location independence." Mobile phones make the task possible to gather and record information from nearly everywhere. They have the highest mobility inside or outside classrooms. The coverage of mobile phones allows teachers to engage in activities requiring ubiquitous tools. With respect to the dimension of "time independence," mobile phones can be used in asynchronous and synchronous learning. SMS and forum messages can be used to support asynchronous learning. Synchronous learning can be facilitated via in-class voting systems and interactive games on mobile phones. They can also be used as real-time assessment tools. The dimension of "meaningful content" is the most critical one. Without quality content, m-Learning will be meaningless. There are many factors adversely 
affecting the delivery of quality content via mobile phones. Slow processing speed, limited bandwidth, small form-factor, limited memory, and one-finger operation are some of them.

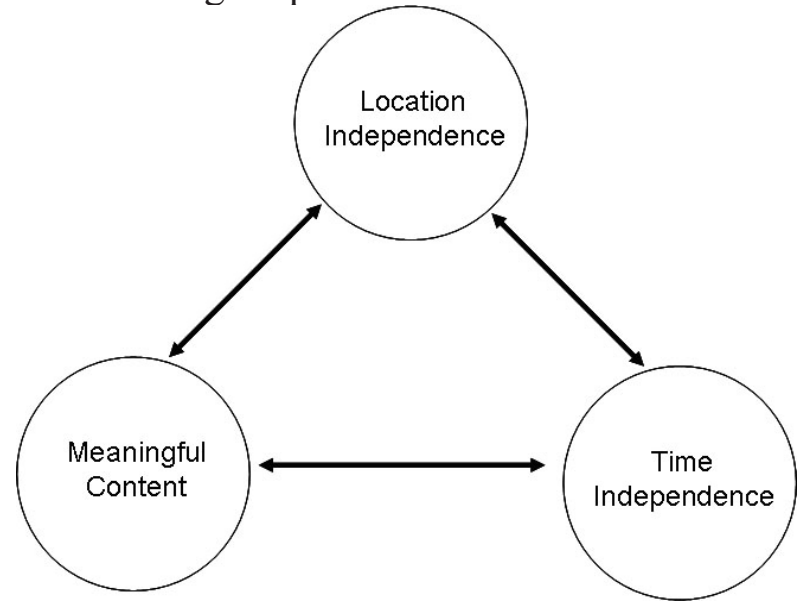

Figure 1. Three important dimensions in m-Learning.

To study the acceptance of mobile phones for teaching and learning, the following three Ws to the research question must be considered:

- WHO are the participants in this study? I have a big class in an undergraduate unit called "Network Management in Schools." This group of pre-service teachers could be better candidates for this research because of their exposure to the networking concepts. Furthermore, they are the younger teachers who will soon venture out in the field. They should be given the opportunities to explore any type of innovative idea for enhancing teaching and learning. As it is not appropriate to occupy their regular lessons for this research, an additional lesson at the end of the unit was conducted.

- WHAT types of activities should I organize to cover my research question? A mobile phone is nothing more than a limited but featured computer. We must recognize the limitations of these devices and develop what they can do best. A voting system, an interactive game, and an assessment platform (i.e. an examination system) were pursued in this study. These activities cover the major directions in m-Learning.

- WHERE can I conduct the activities? To minimize the interference to my students, one-off experiment was performed and a questionnaire was used to collect their opinions. These instruments took place within a classroom environment.

\section{Methodology}

In this research, three activities were developed to address different applications of mobile phones for teaching and learning. Simulators developed to execute in real mobile phones are used for this study (Openwave, 2006). There are three reasons for this approach. First, the chosen software has been implemented in a number of real phone models. It behaves like a real phone. Second, many students may not have mobile phones with advanced features to support WAP 2.0 (Wapforum, 2006). Some students may still have text-based mobile phones. Third, as long as students operate the simulator (e.g. onefinger operation) as the experiment intended, I have a better controlled environment to answer my research question.

To support the experiment of this research or any m-Learning application in general, a WAP gateway connected to a Web server is needed. Figure 2 (on the next page) outlines the system architecture to support the applications over mobile devices. Apache, PHP and MySQL were chosen as the Web server, serverside programming, and database support respectively.

Among the three applications developed for this experiment, the first application is a voting system. Students can cast their votes 


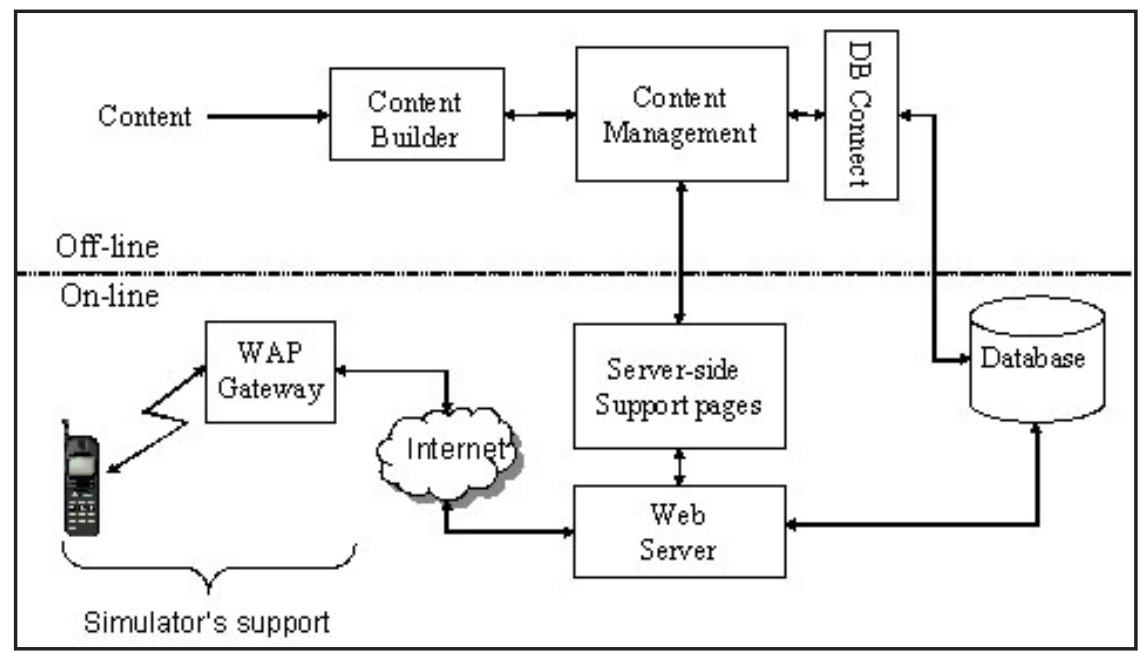

Figure 2. The system architecture to support this m-Learning project.

and teachers can interactively check the voting results as shown in Figure 3 and Figure 4. Students can use the quick access keys ("1" to "X") on the phone keypad to cast their votes. The fragment of XHTML-MP codes for Figure 3 is shown in Figure 5 (on the next page). This acts as if the voter has a simple voting machine or a student response system at hand. Teachers can retrieve the voting results from the database onto their handsets as well.

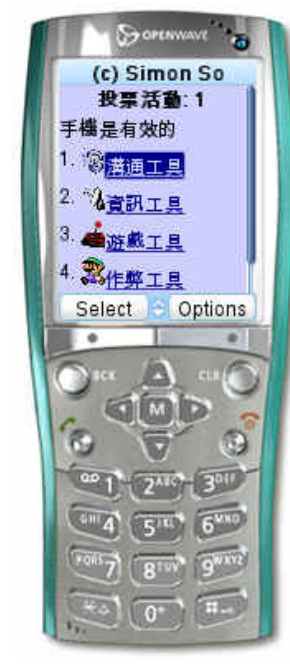

Figure 3. A voting activity

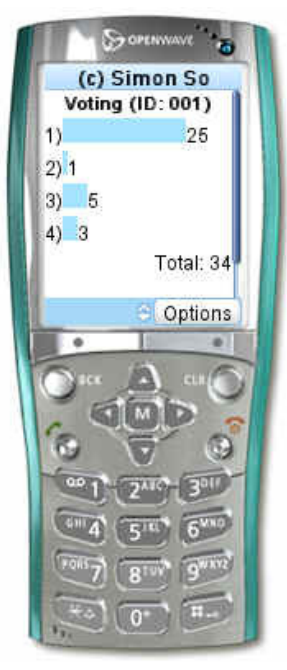

Figure 4. The corresponding voting result.

The second application is an interactivegame called " $15 / 16$ " which is a popular television game show in Hong Kong. Instead of involving two players per game, it was modified that the whole class could participate in each game. Students make their selections and the teacher (or any student) suggests the explanation. Students can change their minds depending upon whether they believe the teacher/students. 


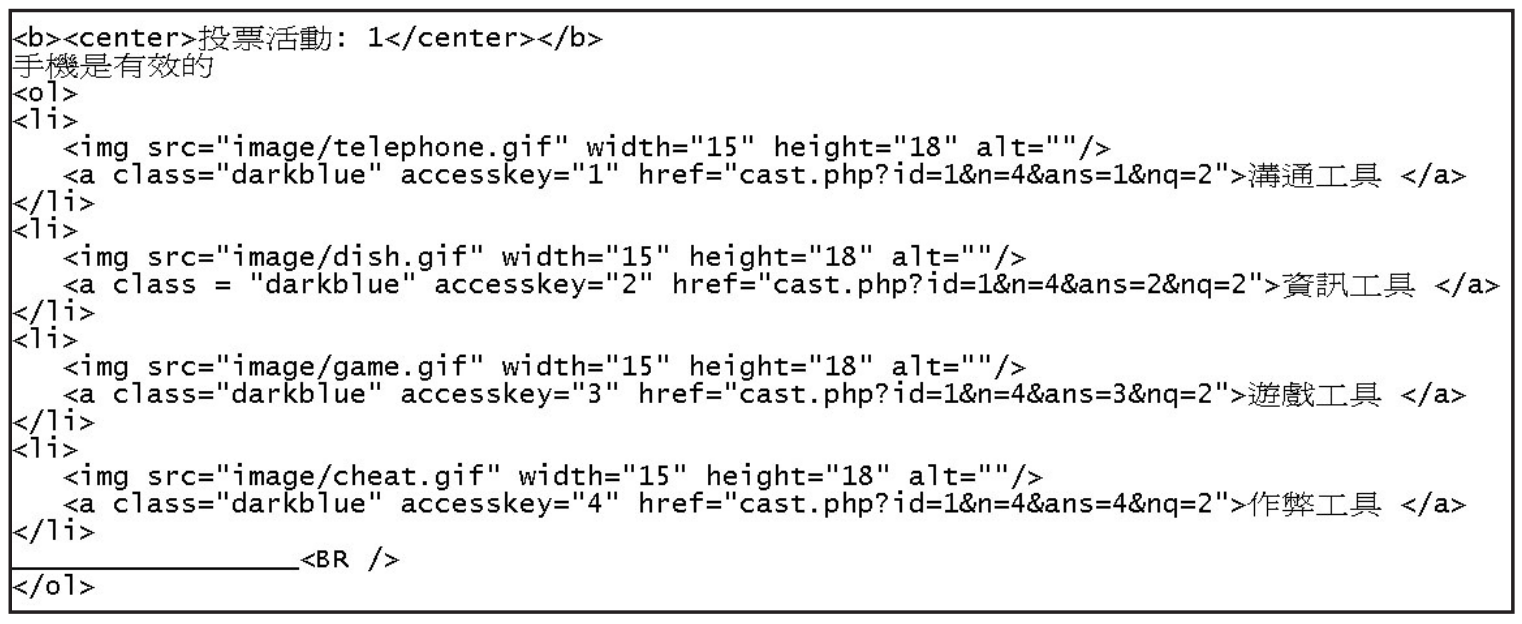

Figure 5. XTHML-MP code fragment for the quick access keys in Figure 3.

Figure 6 illustrates two questions. Teachers can show or refresh students' selections at anytime as shown in Figure 7.
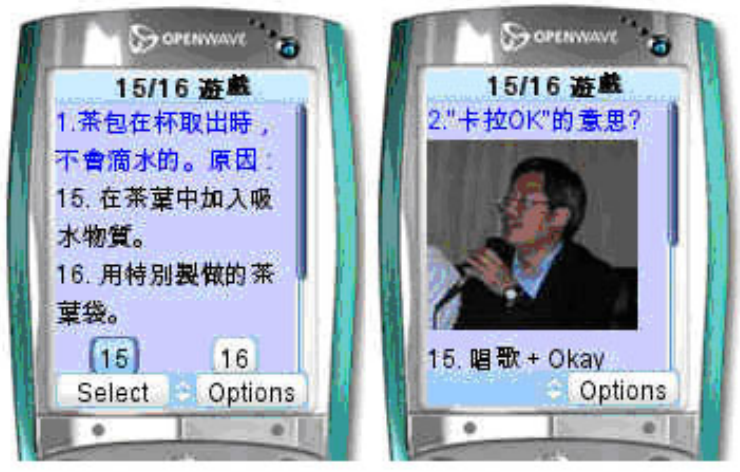

Figure 6. Two questions from the " $15 / 16$ " interactive game.

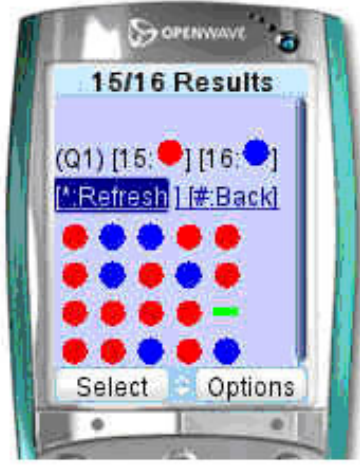

Figure 7. Students' selections
The third application is a system to administrate tests or examinations. Students attempt the questions stored in the database. The overall score can be sent to the students at the end of the test as shown in Figure 8 and Figure 9. The scores are kept in the database as well.
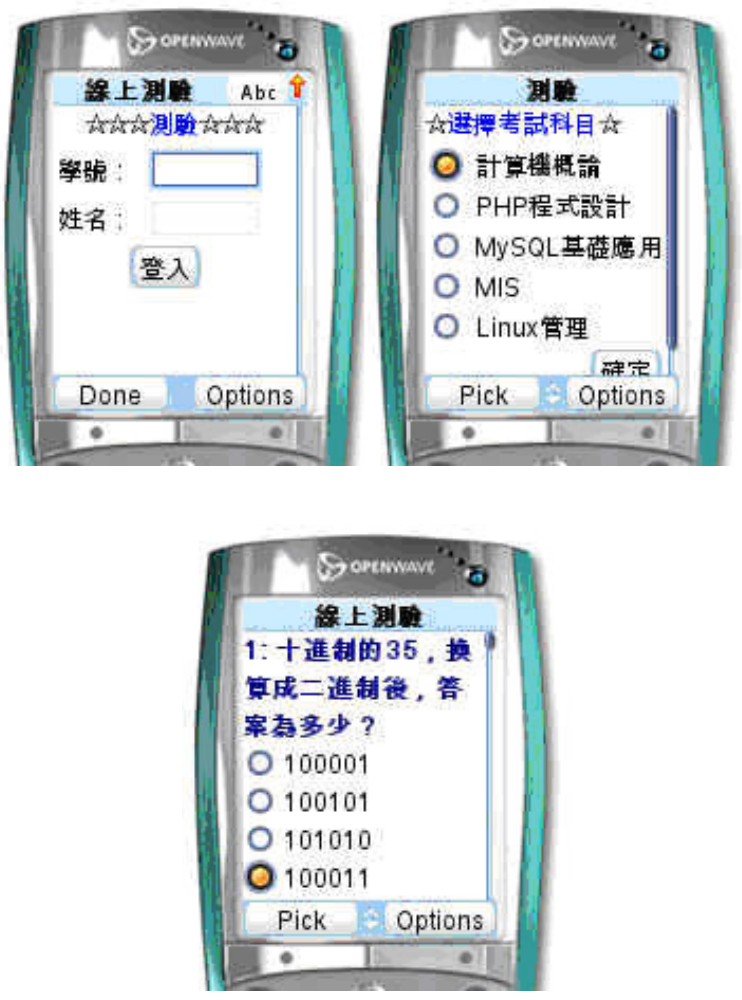

Figure 8. A test on mobile phones. 


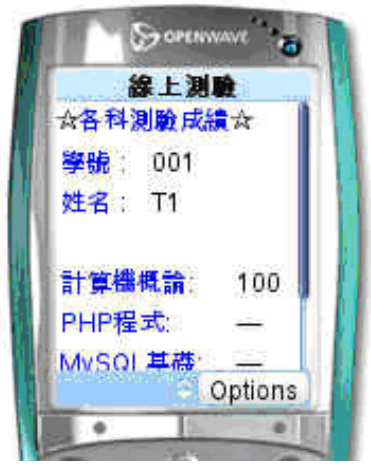

Figure 9. The score

The implementation of the " $15 / 16$ " game on actual Nokia handsets is shown in Figure 10. Students can use the suitable handsets to participate with the activities.

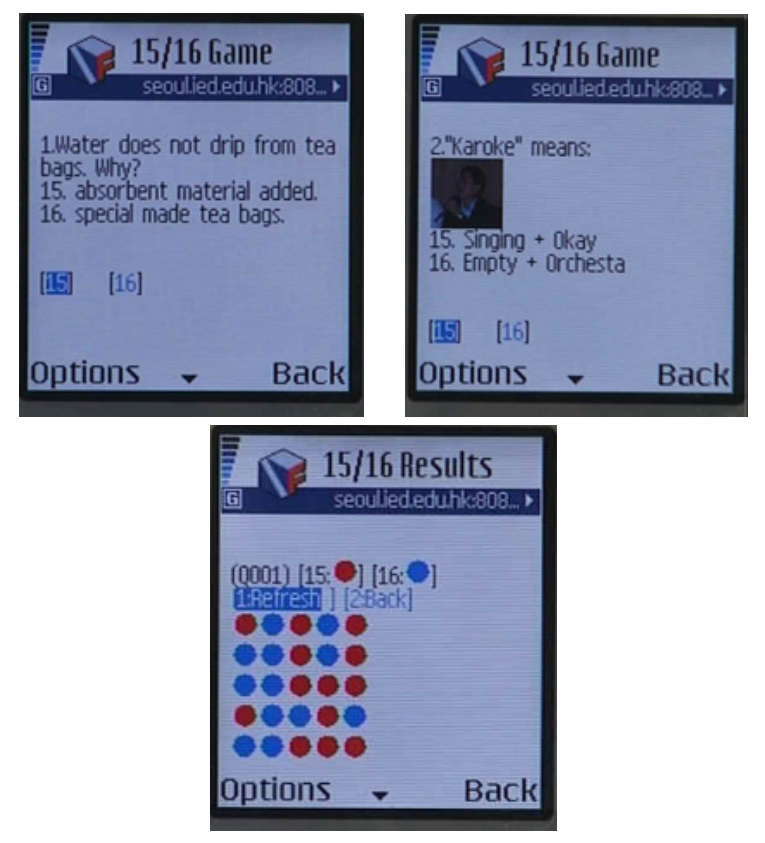

Figure 10. The "15/16" game on Nokia Handsets.
Two main groups of data were collected in this research. The first data set was obtained in real-time from the activities themselves. Figure 11 shows the sample data for the " $15 / 16$ " game in MySQL.

The second data set was from the questionnaire. The questions could be categorized into the following four areas:

1. Basic information - to establish the background of the students.

2. Handset and service information - to find out the types, mobile service providers, tariffs, and services used (e.g. $2.5 \mathrm{G}$ or $3 \mathrm{G}$ ).

3. Phone usage and practice - to survey information such as airtime, SMS, MMS, ring-tone download, Internet, and other usages.

4. Attitude - to find out how the students feel about the use of mobile phones for teaching and learning.

\section{Data Collection and Analysis}

A total of twenty-four students completed the three activities and the survey. The data obtained from the questionnaire were keyed into the database for analysis

\subsection{Demographics}

Table 1 and Table 2 (on the next page) provide a demographic overview of the respondents with respect to age, gender, handset brands, and types of mobile services.

\begin{tabular}{|c|c|c|c|c|c|c|c|c|}
\hline $\begin{array}{l}\leftarrow \top \rightarrow \\
\Gamma \bullet x\end{array}$ & $\begin{array}{r}\text { Question } \\
2\end{array}$ & $\begin{array}{r}\text { ents } \\
30\end{array}$ & $\begin{array}{r}01 \\
1\end{array}$ & $\begin{array}{r}02 \\
1\end{array}$ & $\begin{array}{r}03 \\
1\end{array}$ & $\begin{array}{r}04 \\
1\end{array}$ & $\begin{array}{r}05 \\
1\end{array}$ & $\begin{array}{r}106 \\
0\end{array}$ \\
\hline$\Gamma x$ & 1 & 30 & 0 & 1 & 1 & 0 & 0 & 0 \\
\hline$\Gamma x$ & 3 & 30 & 0 & 0 & 1 & 0 & 0 & 0 \\
\hline
\end{tabular}

Figure 11. Sample data of the "15/16" game. 
Table 1. Age, gender and mobile services

\begin{tabular}{|c|c|}
\hline \multicolumn{2}{|c|}{ Age $\quad$ Gender } \\
\hline 16-20 у.о. $4 \% \quad$ Male & $21 \% 3 \mathrm{G}$ \\
\hline $21-25$ у.о. $96 \%$ Female & $79 \% \quad 2 / 2.5 \mathrm{G} \quad 67 \%$ \\
\hline \multicolumn{2}{|l|}{ Table 2. Handset brands } \\
\hline \multicolumn{2}{|c|}{ Handsets owned by the pre-service teachers } \\
\hline Nokia & $34 \%$ \\
\hline Sony Ericisson & $25 \%$ \\
\hline Motorola & $8 \%$ \\
\hline Samsung & $8 \%$ \\
\hline others & $25 \%$ \\
\hline
\end{tabular}

Because the respondents are from a single class of pre-service teachers taking Information Technology as their minor study, the classification of age group is quite close. Also, the distribution of male and female respondents represents the typical composition of any education programme in the Hong Kong Institute of Education.

With no surprise, Nokia is the leader on the market for handsets with 34\%, followed by Sony Ericisson (25\%). About $1 / 3$ of the respondents use $3 \mathrm{G}$ services and spend on average HK\$107 (from the database) per month with the average air-time plan of 1020 minutes.

\subsection{Usage and practice}

The following tables (Table $3-5$ ) reveal how the respondents use mobile phones for different purposes. Most of the recent handsets are equipped with cameras, true color displays, stereo sound, and external memory cards. They can be multi-purpose for the students as shown in the data.
Table 3. Talk time

\begin{tabular}{ll}
\hline \multicolumn{2}{c}{ Voice communication per day } \\
\hline Less than 3 minutes & $0 \%$ \\
3 - 5 minutes & $4 \%$ \\
6 - 10 minutes & $4 \%$ \\
11 - 15 minutes & $13 \%$ \\
16 - 30 minutes & $42 \%$ \\
31 - 60 minutes & $33 \%$ \\
Over 1 hour & $4 \%$ \\
\hline
\end{tabular}

Table 4. SMS and MMS usages

\begin{tabular}{lllll}
\hline & $\begin{array}{l}\text { SMS } \\
\text { Received }\end{array}$ & $\begin{array}{l}\text { SMS } \\
\text { Sent }\end{array}$ & $\begin{array}{l}\text { MMS } \\
\text { Received }\end{array}$ & $\begin{array}{l}\text { MMS } \\
\text { Sent }\end{array}$ \\
\hline $\begin{array}{l}\text { Less } \\
\text { than 3 }\end{array}$ & $17 \%$ & $17 \%$ & $83 \%$ & $83 \%$ \\
$3-4$ & $17 \%$ & $21 \%$ & $17 \%$ & $13 \%$ \\
$5-10$ & $13 \%$ & $13 \%$ & $0 \%$ & $4 \%$ \\
$11-20$ & $21 \%$ & $17 \%$ & $0 \%$ & $0 \%$ \\
$21-30$ & $4 \%$ & $4 \%$ & $0 \%$ & $0 \%$ \\
$\begin{array}{l}\text { More } \\
\text { than 30 }\end{array}$ & $29 \%$ & $29 \%$ & $0 \%$ & $0 \%$ \\
\hline
\end{tabular}

Table 5. Handset usage

Smart phones are being used for different purposes

\begin{tabular}{ll}
\hline Playing games & $71 \%$ \\
Taking memos & $50 \%$ \\
Taking photos & $88 \%$ \\
Watching movies & $13 \%$ \\
Listening songs & $42 \%$ \\
Surfing Internet & $4 \%$ \\
\hline
\end{tabular}


While the majority of them use mobile phones for voice communication $(47 \%$ of the respondents, on average, talk for $16-30$ minutes per day), other usages such as taking photos (88\%) and playing games $(71 \%)$ dominate different practices.

Sending and retrieving SMS messages are quite popular among the respondents, but sending and retrieving MMS messages remain low.

\subsection{Acceptance of mobile phones for teaching and learning}

This section provides answers to the focus of this research. Respondents were asked to express their views on using mobile phones for teaching, learning, and administrative purposes. After they have just experienced the activities described above, respondents could articulate their difficulties in utilizing the mobile devices. They were also asked to provide their opinions on issues like secondary students taking mobile phones to schools, communicating with parents using SMS messages, and incorporating the topic of "m-Learning" into their curriculum as shown in Table 6 and Table 7.

Table 6. The difficulty of using mobile phones for teaching and learning

\begin{tabular}{ll}
\hline Area & Percentage \\
\hline Text input & $58 \%$ \\
Small screen & $67 \%$ \\
Slow connectivity & $58 \%$ \\
Too expensive & $46 \%$ \\
Difficult to use & $33 \%$ \\
\hline
\end{tabular}

Table 7. Acceptance of mobile phones for teaching and learning

\begin{tabular}{lllll}
\hline & $\begin{array}{l}\text { Strongly } \\
\text { disagree }\end{array}$ & Disagree & Agree & $\begin{array}{l}\text { Strongly } \\
\text { agree }\end{array}$ \\
\hline $\begin{array}{l}\text { Mobile phones can improve the quality of } \\
\text { education }\end{array}$ & $42 \%$ & $54 \%$ & $0 \%$ \\
$\begin{array}{l}\text { I am interested to use mobile phones as } \\
\text { teaching and learning tools }\end{array}$ & $29 \%$ & $63 \%$ & $4 \%$ \\
$\begin{array}{l}\text { Mobile phones can be used to assist teaching } \\
\text { and learning }\end{array}$ & $25 \%$ & $63 \%$ & $4 \%$ \\
$\begin{array}{l}\text { Mobile phones can be effective tools in } \\
\text { classrooms and at distance learning }\end{array}$ & $25 \%$ & $67 \%$ & $0 \%$ \\
$\begin{array}{l}\text { Mobile phones can be used for administrative } \\
\text { purposes (e.g. send SMS messages to } \\
\text { parents) }\end{array}$ & $21 \%$ & $71 \%$ & $4 \%$ \\
$\begin{array}{l}\text { Should secondary students bring their mobile } \\
\text { phones to schools? }\end{array}$ & & & \\
$\begin{array}{l}\text { Do you want to see "m-Learning" be part of } \\
\text { your curriculum? }\end{array}$ & $3 \% \%$ & $63 \%$ & $0 \%$ \\
\hline
\end{tabular}


This study shows that the majority of the respondents generally accepted the use of mobile phones for teaching and learning. They found the inhibiting factors are accordingly small screens, text input, slow connectivity, expensive, and difficult to use.

They somewhat agreed that mobile phones can improve the quality of education (54\%). Their curiosity in using mobile phones for teaching and learning is high $(67 \%$ : $63 \%+4 \%)$. The respondents have quite a liberal mind in allowing secondary students to bring mobile phones to schools $(87 \%$ : $79 \%+8 \%)$. They would like to use mobile phones for administrative purposes (75\%: $71 \%+4 \%)$. They were somewhat interested to see "m-Learning" become part of their curriculum.

\section{Discussion}

In this study, the focus is to discover the acceptance of mobile phones for teaching and learning by a group of pre-service teachers. The experiment was generally well-received by my students. They found that it is fun to participate in the exercise. The findings of this study are summarized in the following:

- The respondents agreed that mobile phones can be used for teaching and learning. However, they were somewhat skeptical towards the quality that mobile phones can bring to education.

- The majority of the respondents were very liberal and interested to use mobile phones for teaching and learning.

- With this age group, SMS messaging was a popular way to communicate.

- Mobile phones were mainly used for talking, texting, taking photographs, and playing games.
Although the sample size is small and the findings may not be reliable, the experiment is very encouraging. Thus, this study provides me with the preliminary data to continue research toward more discriminating experiments on $\mathrm{m}$-Learning.

I found the activity such as the " $15 / 16$ " game a great way to motivate students and foster interaction among participants. This was not only applicable to the field of $\mathrm{m}$-Learning, but also as a general pedagogical technique in teaching and learning.

\section{References}

Alamäki, H., \& Seppälä, P. (2002). Experimenting with mobile learning in a university environment, Proceedings of the 2002 World Conference on E-Learning in Corporate, Government, Healthcare, \& Higher Education (pp.67-74), E-LEARN 2002.

Andronico, A., Carbonaro, A., Colazzo, L., Molinari, A., Ronchetti, M., \& Trifonova, A. (2004). Designing models and services for learning systems in mobile settings, Mobile and Ubiquitous Information Access Workshop 2003, LNCS 2954, 90-106, Springer-Verlag: Berlin Heidelberg

BECTA (2003). Handheld Computers (PDAs) in Schools, UK. BECTA, U.K.

BECTA (2007). Ubiquitous computing, Emerging Technologies for Learning. Vol. 2. BECTA, U.K.

Csete, J., Wong, Y., \& Vogel, D. (2004). Mobile devices in and out of the classroom, Proceedings of the 2004 World Conference on Educational Multimedia, Hypermedia and Telecommunications (pp.4729-4736), ED-MEDIA2004, Lugano, Switzerland.

Duke. (2008). Mobile Devices in Education. Center for Instructional Technology, Duke University. Retrieved March 1, 2008 from 
http://cit.duke.edu/tools/mobile/index.html

E3Learn (n.d.).. Hong Kong Polytechnic University. Retrieved May 29, 2007 from http://e3learning.edc.polyu.edu.hk/

EDUCAUSE. (n.d.). Handheld and Mobile Computing. Retrieved March 1, 2008 from http://connect.educause.edu/browse/ content $/$ lib_item $/ 533$ ?class $=$ publications

Futurelab. (2004). Literature review in mobile technologies and learning. Retrieved 29th May2007fromhttp:/www.futurelab.org.uk/ resources/documents/lit_reviews/Mobile Review.pdf

Futurelab. (2006). Learning with handheld technology. Retrieved May 29, 2007 from http://www.futurelab.org.uk/resources/ documents/handbooks/handhelds handbook.pdf

Harvard. (2007). Handheld devices for ubiquitous learning project summary. Retrieved March 1, 2008 from http:// gseacademic.harvard.edu/ hdul/

Hayes, P., Joyce, D., \& Pathak, P. (2004). Ubiquitous learning - An application of mobile technology in education, Proceedings of the 2004 World Conference on Educational Multimedia, Hypermedia and Telecommunications (pp.1811-1816), ED-MEDIA2004, Lugano, Switzerland.

Heath, B., Herman, R., Lugo, G., Reeves, J., Vetter, R., \& Ward, C. (2005). Project Numina: Enhancing student learning with handheld. IEEE Computer. June 2005.

JISC. (2005). Innovative practice with e-Learning: A good practice guide to embedding mobile and wireless technologies into everyday practice. Joint Information Systems Committee, U.K.

Learning2Go. (2008). 21st Century mobile learning becomes reality for learners in the City of Wolverhampton. Retrieved March 1, 2008 from http://www.learning2go.org/

McManus, T. (2002). Mobile what? The educational potential of mobile technologies, Proceedings of the 2002
World Conference on E-Learning in Corporate, Government, Healthcare, \& Higher Education (pp.1895-1898), E-LEARN 2002.

Mobile Learning. (2006). The next generation of learning. Retrieved 29th May 2007 from http://learning.ericsson.net/mlearning2/ project.shtml

MOBIlearn. (2005). MOBIlearn project consortium. Retrieved September 1, 2007 from http://www.mobilearn.org/

M-Learning. (n.d.). Knowledge center. CTAD. Retrieved March 1, 2008 from http:// www.m-learning.org/knowledge-centre/ knowledge-centre.htm

NAEC. (2006). Ultralab projects. National Archive of Educational Computing, U.K. Retrieved May 29, 2007 from http://www. naec.org.uk/ultralab/ww3/projects

Openwave. (2006). V7 simulator. Retrieved April 14, 2006, from http://www.openwave. com

Scheele, N., Seitz, C., Effelsberg, W., \& Wessels, A. (2004). Mobile devices in interactive lectures, Proceedings of the 2004 World Conference on Educational Multimedia, Hypermedia and Telecommunications (pp.154-161), ED-MEDIA2004, Lugano, Switzerland.

OFTA. (2008). Hong Kong: The facts. Office of the Telecommunications Authority. HKSAR. Retrieved March 1, 2008 from http://www.gov.hk/en/about/ abouthk/factsheets/docs/telecommuni cations.pdf

Sharples, M. (2007). Big issues in mobile learning: Report of a workshop by the Kaleidoscope Network of Excellence Mobile Learning Initiative. Learning Sciences Research Institute, University of Nottingham. Nottingham, U.K.

Consortium, S. (2002). mLearning: Mobile learning: A university in your pocket? Retrieved May 29, 2007 from http://www. sloan-c.org/effective/details2.asp?ACC_ 
$\mathrm{ID}=22$

Smørdal, O., \& Gregory, J. (2005). KNOWMOBILE: Mobile opportunities for medical students, in A. Kukulska-hulme and J. Traxler (eds), Mobile learning: A handbook for educators and trainers. London: Routledge.

Wapforum. (2006). WAP 2.0 standard. Retrieved May 20, 2006 from http:/www. wapforum.org

\section{Contact the Author}

Simon So, Ph.D.

Hong Kong Institute of Education

Email:swwso@ied.edu.hk 